\title{
Improving Hearing Impaired Students' Assertive Behavior through Parachute Games
}

\author{
Berliana Berliana* \\ Program Studi Pendidikan Olahraga, Sekolah Pascasarjana \\ Universitas Pendidikan Indonesia \\ Bandung, Indonesia \\ *berliana.rahely@yahoo.co.id
}

\begin{abstract}
The study was aimed to investigate the effect of parachute games on hearing impaired students' development on their assertive behavior. An experiment method using The Randomized Pretest-Posttest Control Group Design was employed to answer the research question. 24 hearing impaired students of SLB Negeri Citeureup Cimahi were involved as sample of the study. Students' assertive behavior was measured by assertive behavior questionnaire whose data were then analyzed through T-Paired test. A calculation of Effect Size was also conducted to find out the effectiveness of parachute games on hearing impaired students' assertive behavior development. The result showed significant value $0.004<0.05$ and Effect Size calculation 0.21. The result of the study shows that parachute games has significant effect in improving hearing impaired students' assertive behavior.
\end{abstract}

Keywords-prachute games; assertive; hearing impaired students

\section{INTRODUCTION}

The study was conducted based on the researcher's observation result to students with disabilities in Sekolah Luar Biasa, particularly students with hearing impairment, when they are not able to express their own feeling. The students tend to face difficulties to refuse other people requests, especially from people with no disabilities whom the students think are better from them. Once they do, they do it aggressively. Besides, the students tend to be afraid of making mistakes that make them really worried. Students who are facing these conditions can be considered as non-assertive students, who tend to feel scared of facing people around them [1]. Meanwhile, assertive individuals will be able to express their emotions, fight for what they want, and be able to build a good interpersonal relationship with others [2].

According to Keilmann, Limberger \& Mann, students with disabilities will feel that they are different from they with no disabilities. They tend to feel unconfident and non-assertive, including students with hearing impairment [3]. Hearing impaired students face difficulties in expressing their feelings, their likes and dislikes [4]. They also tend to be introvert and are not able to express whatever they are feeling [5].
Despite the disabilities they have, hearing impaired students have physical condition that are the same with people without disabilities as hearing impairment is doesn't equal to a disability to learn something. Hearing impairment will usually have effects on student's ability to express their thoughts orally and on their social interaction that is able to make them feel isolated and discarded [6]. Due to the equal physical condition to those on people without disabilities as have been mentioned above, hearing impaired students also have the same opportunities to have physical activities to improve their social interaction. "For many Deaf adults, participation in Deaf sport events is a major means of socialization. Deaf sport provides a place for meaningful interactions with others" [7]. Participation in physical activity and sports has been strongly encouraged in young people with disabilities for developing their psychosocial skills, performance, and competence [8].

Physical activity in the current study refers to physical activity through game activity that can be one of ways where hearing impaired students to socialize with others. Games are an interesting and fun physical activity for students with disabilities which in turn will give positive contribution to their health condition [9]. A game that is employed in this study is parachute game. "Parachute games are an exciting way to develop cooperation skills, self-confidence, empathy, communication skill and emotional literacy. In addition, they are incredible fun" [10].

Assertive behavior aspect on hearing impaired students is considered important to be investigated since to help them fighting for their individual rights by showing assertive behavior and to assist them expressing their feelings. This study was conducted as an attempt to help students with disabilities having courage and being a brave individual that is able to fight for their rights in their social life.

\section{METHOD}

\section{A. Participant}

The sample of the study were 24 hearing impaired students in one Sekolah Luar Biasa (SLB) in Citeureup Cimahi. The sampling technique that was used is Total Population Sampling since the sample that was investigated is relatively small [11]. 


\section{B. Procedurs}

The study was set as an experimental study that used Pretest Post-Test Design in which 8 meetings of treatment was conducted to collect the data [12]. The programs of conducting the study can be seen in the following table [13]:

TABLE I. PROGRAMS IN CONDUCTING THE STUDY

\begin{tabular}{|c|c|c|}
\hline NO & PARACHUTE GAME & ASSERTIVE PROGRAM \\
\hline 1 & $\begin{array}{l}\text { Excitaball (Bola yang } \\
\text { Menarik) }\end{array}$ & $\begin{array}{l}\text { Treatment to help students } \\
\text { expessing themselves }\end{array}$ \\
\hline 2 & $\begin{array}{l}\text { Side to Side (Sisi ke } \\
\text { Sisi) }\end{array}$ & $\begin{array}{l}\text { Treatment to help students } \\
\text { respecting others }\end{array}$ \\
\hline 3 & $\begin{array}{l}\text { Jumping Bean (Kacang } \\
\text { yang melompat) }\end{array}$ & $\begin{array}{l}\text { Treatment to help students } \\
\text { showing their feelings bravely }\end{array}$ \\
\hline 4 & High Ball (Bola Tinggi) & $\begin{array}{l}\text { Treatment to help students being } \\
\text { honest with their condition }\end{array}$ \\
\hline 5 & $\begin{array}{l}\text { Snap and } \\
\text { (Hentakan } \\
\text { Tangkap) }\end{array}$ & $\begin{array}{l}\text { Treatment to help students } \\
\text { controlling their anger }\end{array}$ \\
\hline 6 & $\begin{array}{l}\text { Pass The Parachute } \\
\text { Along }\end{array}$ & $\begin{array}{l}\text { Treatment to help students being } \\
\text { calm }\end{array}$ \\
\hline 7 & $\begin{array}{l}\text { Shaking all } \\
\text { (Guncangkan } \\
\text { semuanya) }\end{array}$ & $\begin{array}{l}\text { Treatment to help students } \\
\text { expressing their dislikes or saying } \\
\text { no }\end{array}$ \\
\hline 8 & $\begin{array}{l}\text { Bucket Ball (Seember } \\
\text { Bola) }\end{array}$ & $\begin{array}{l}\text { Treatment to help students to } \\
\text { communicate }\end{array}$ \\
\hline
\end{tabular}

\section{Instruments}

Data of the study were collected through assertive behavior questionnaire, an instrument to measure students' assertive behavior that is arranged based on assertive behavior indicators. The questionnaire consists of 80 items of questions. The data were then proceeded and analyzed by using the T-Paired Test on SPSS 21.

\section{RESULTS AND DISCUSSION}

\section{A. Data Description}

Results of measurements on students' assertive behavior were used to answer the research question.

TABLE II. DATA DESCRIPTION OF STUDENTS ASSERTIVE BEHAVIOR

\begin{tabular}{|l|c|l|l|l|l|l|}
\hline \multicolumn{7}{|c|}{ Descriptive Statistics } \\
\hline & $\boldsymbol{N}$ & Min & Max & Mean & $\begin{array}{c}\text { Std. } \\
\text { Deviation }\end{array}$ & Variance \\
\hline Pretest of Parachite games & 12 & 67 & 97 & 79.7500 & 10.66963 & 113.841 \\
\hline Posttes of Parachute games & 12 & 68 & 104 & 82.3333 & 12.81571 & 164.242 \\
\hline Valid N (listwise) & 12 & & & & & \\
\hline
\end{tabular}

Based on the table 2 above, it can be seen that there is an improvement of students score of assertive behavior in pretest to postest, where students ${ }^{6}$ average score in pretest 79,75 increase to average 82,33 in postest. This result indicates that there is an improvement on hearing impaired students' assertive behavior. Thus, it can be concluded that parachute games have significant effects in improving students' assertive behavior in SLB Negeri Citeureup.

\section{B. Statistics Assumption Test}

TABLE III. RESULT OF NORMALITY TEST OF ASSERTIVE BEHAVIOR

\begin{tabular}{|c|c|c|c|c|c|c|c|}
\hline \multicolumn{8}{|c|}{ Tests of Normality } \\
\hline \multirow{2}{*}{\multicolumn{2}{|c|}{ Measurement }} & \multicolumn{3}{|c|}{ Kolmogorov-Smirnov ${ }^{\text {a }}$} & \multicolumn{3}{|c|}{ Shapiro-Wilk } \\
\hline & & Statistic & $d f$ & Sig. & Statistic & $D f$ & Sig. \\
\hline \multirow{2}{*}{ grade } & Pretest & .185 & 12 & $.200 *$ & .901 & 12 & .166 \\
\hline & Posttest & .216 & 12 & .129 & .890 & 12 & .119 \\
\hline \multicolumn{8}{|c|}{ *. This is a lower bound of the true significance } \\
\hline & & & & & a. Lillie & Significan & orrectic \\
\hline
\end{tabular}

The table above shows that significant value on Pretest by using Shapiro-Wilk is 0.166 , and 0.119 on Posttest. The data shows that significant values are higher than 0,05 as the limit to reject the hypothesis. Then, it can be concluded that the sample of the study comes from population that are normally distributed.

TABLE IV. RESULT OF HOMOGENITY TEST

\begin{tabular}{|c|c|c|c|}
\hline \multicolumn{4}{|c|}{ Test of Homogeneity of Variances } \\
\hline \multicolumn{4}{|c|}{ grade } \\
\hline Levene Statistic & $\boldsymbol{d f 1}$ & $\boldsymbol{d f} \mathbf{2}$ & Sig. \\
\hline .876 & 1 & 22 & .359 \\
\hline
\end{tabular}

Table 4 reveals that the significant values are higher than a $0,05(0,359>0,05)$. Thus, it is save to conclude that the data comes from populations who have the same variance.

\section{Results of the Study}

TABLE V. RESUlT OF INVESTIGATION ON ASSERTIVE BEHAVIOR

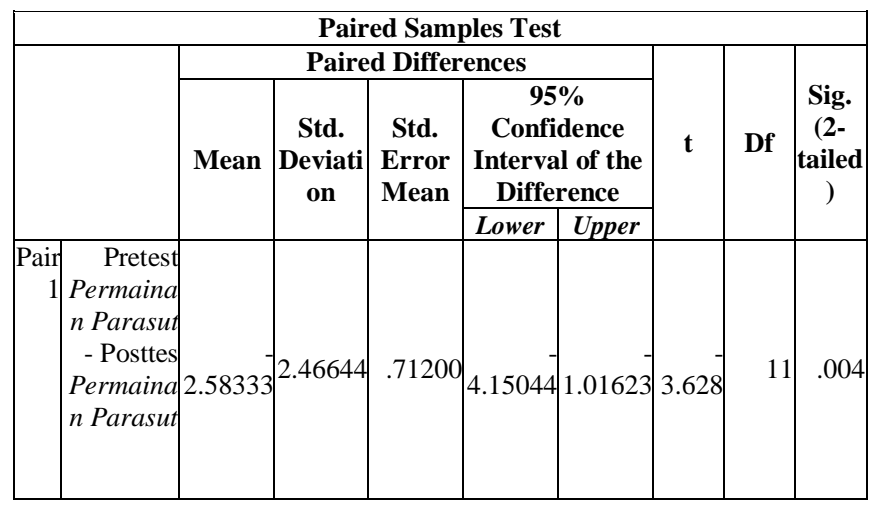

The criterion that is used in this study is when significant value (2-tailed) $<0.05$, then Ho is rejected. In the other hand, when significant value (2-tailed) $>0.05$, then Ho is accepted. Table 4 above shows that significant value of student's assertive behavior by using parachute games is 0,004 , then it is enough to reject Ho and to accept $\mathrm{H} 1$, meaning that parachutes games have significant impacts in improving hearing impaired students' assertive behavior. 


\section{Effect Size}

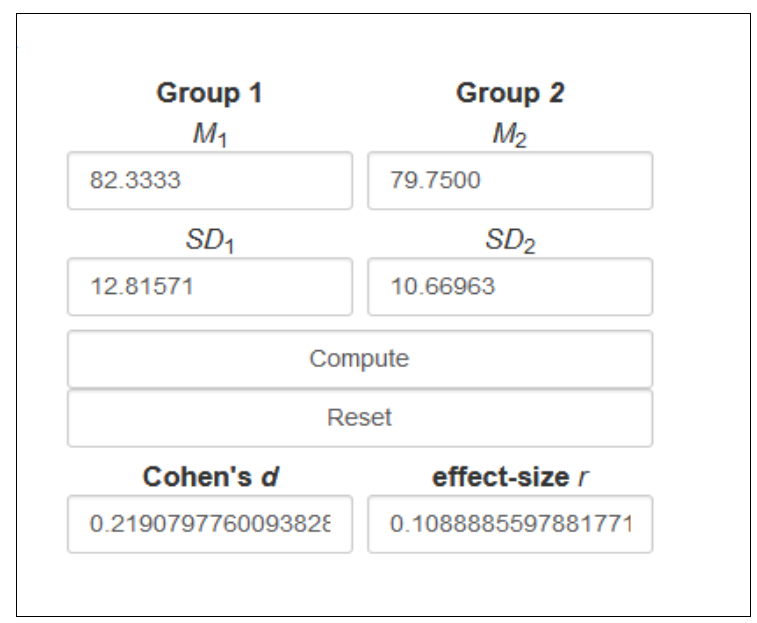

Fig. 1. Result of effect size measurement by using effect size calculator [14].

Effect size refers to a measurement on significance of study results that is able to show the amount of correlation or difference, or to show effects between variables, one to another. This measurement completed information about analysis results given by significance test.

Based on the figure above, effect size score of the study is 0.219. According to Cohen, it can be interpreted that the effects of parachute games can be categorized into small effect category. This may due to the small intensity of the treatments given. It was also found in the study that treatments that are less than six sessions of treatment have no significant effect in improving students' assertive behavior [15].

Thus, it can be assumed that parachute games have effects in improving hearing impaired students' assertive behavior, although it is still categorized into small effects. Through parachute games, the students are allowed to interact one to another and to do many physical activities such as touching the soft fabric of parachute, moving around on the parachute, lying down under parachute, watching others moves up and down, or even being covered by the parachute. For children and even adults, those can be interesting activities that will enable them to work together, to communicate, have social interaction, and to create unforgettable experience and have lots of fun. This kind of condition is able to improve students' confidence [16] as they are able to perform what is instructed by the teacher without feeling scared or under pressured. When hearing impaired students feel happy and are engaged in the game activities, they will feel confident which in turn will enable them to be brave to express what they are feeling and will make them able to fight for their individual rights, signs of assertive behavior improvement.

\section{CONCLUSION}

From the result of the study, some conclusion can be drawn. First, parachute games are an important component in giving intervention to students with disabilities, particularly hearing impaired students. Second, parachute games can have used to help students to communicate between one to another, express their feelings through parachute media, and help the students to be happier in doing their activities. Third, the effects of parachute games activities to improve students' assertive behaviour will be more effective when the treatments are given more regularly.

\section{REFERENCES}

[1] Y.R. Lin, I.S. Shiah, Y.C. Chang, T.J. Lai, K.Y. Wang and K.R. Chou, "Evaluation of an assertiveness training program on nursing and medica students' assertiveness, self-esteem, and interpersonal communication satisfaction," Nurse education today, vol. 24, no. 8, pp. 656-665, 2004.

[2] F. Yong, "A Study on the assertiveness and academic procrastination of english and communication students at a private university," American Journal of Scientific Research, vol. 9, pp. 62-72, 2010.

[3] Keilmann, Annerose, Annette Limberger and W.J. Mann, "Psychological and Physical Well-Being in," International Journal of Pediatric Otorhinolaryngology, vol. 71, pp. 1747-1752, 2007.

[4] C. Cambra, "Feelings and emotions in deafness," Deafness and Education International, vol. 7, no. 4, pp. 195-205, 2005.

[5] M.M. Terwogt and Rieffe, "Behavioral Problems in Deaf Children: Theory of Mind Delay or Communication Failure?" Eur. J. Dev. Psychol., vol. 1, pp. 231-240, 2004.

[6] P.G. Jacobs, Deafness-Specific Tactic Knowledge: A New Understanding of Mental Health, and Social and Professional Participation. Melbourne: Australia, 2012.

[7] D.A. Stewart, "Sport And The Deaf Child," American Annals Of The Deaf, vol. 150, no. 1, pp. 59-66, 2005.

[8] Y. Hutzler, A.C. Guber and Reiter, "Psychosocial Effects Of ReverseIntegrated Basketball Activity Compared To Separate And No Physical Activity In Young People With Physical Disability," Research In Developmental Disabilities, vol. 34, pp. 579-587, 2012.

[9] C.Y. Pan, C.W. Liu, I.C. Chung and P.J. Hsu, "Physical activity levels of adolescents with and without intellectual disabilities during physical education and recess," Res Dev Disabil., vol. 36, pp. 579-586, 2015.

[10] J. Mosley and H. Sonnet, Making Wapes. Exciting Parachute Games To Develop Self Confidence And Team-Building Skills. Nottingham: Victoria Business Park Nga 2sg Uk, 2002.

[11] I. Etikan, S.A. Musa and R.S. Alkassim, "Comparison of Convenience Sampling and Purposive Sampling," American Journal of Theoretical and Applied Statistics, vol. 5, pp. 1-4, 2016.

[12] J.R. Fraenkel, N.E. Wellen and H. Hyun, How To Design And Evaluate Research In Education. New York: McGraw-Hill Inc., 2012.

[13] F. Avşar and S.A. Alkaya, "The Effectiveness of Assertiveness Training for School-Aged Children on Bullying and Assertiveness Level," Journal of Pediatric Nursing, vol. 36, pp. 186-90, 2017.

[14] Becker, "Effect Size Calculators," [Online]. Retrieved from https://www.uccs.edu/lbecker/

[15] M.M. Meyer, "The effects of assertion training on assertive behaviors, self-acceptance, self-concept, and locus-of-control," Unpublished.

[16] A.O. Solihin, "Permainan Menggunakan Parasut Serta Pengaruhnya Terhadap Kerjasama Siswa Tunarungu," Motion, vol. 4, no. 2, 2015. 